\title{
Construções retórico-argumentativas em Júlio César, de Shakespeare
}

\section{Fábio Ávila Arcanjo}

Doutorando em Estudos Linguísticos pela Universidade Federal de Minas Gerais (UFMG), Brasil. Bolsista CNPQ.

fabioarcanj01981@hotmail.com

\section{Thiago Fernandes Peixoto}

Doutorando em Estudos Linguísticos pela Universidade Federal de Minas Gerais (UFMG), Brasil. Bolsista FAPEMIG.

thfpeixoto@gmail.com

Resumo: No presente artigo, analisamos, a partir de uma visão retórico-discursiva, o Ato III, Cena II, da peça Júlio César, de William Shakespeare, no qual temos dois célebres discursos da história da literatura (proferidos pelos personagens Brutus e Marco Antônio), decorrentes do assassinato do imperador César. Para tanto, valemonos de autores como Aristóteles (2005), Fiorin (2016), Perelman e Olbrechts-Tyteca (1996), destacando as noções de emoção e valor, além de elementos de ordem linguística essenciais para o funcionamento da argumentação. No corpus analisado, notamos a presença de estratégias que visam à mobilização e à adesão do auditório às teses defendidas pelos oradores, destacando que esses discursos são proferimentos antagônicos, direcionados a um mesmo auditório. Nesse sentido, a mobilização de valores, bem como as estratégias citadas são distintas e apontam para direções opostas em relação aos efeitos desejados.

Palavras-chave: Nova retórica. Argumentação. Emoções. Valores.

\begin{abstract}
In this article, we analyzed, based on a rhetorical discursive view, the Act III, Scene II of the play Julius Caesar, by Shakespeare, in whom we have two celebrated discourses of the history of the literature (pronounced by the characters Brutus and Mark Antony), motivated by the murder of the emperor Caesar. For this purpose, we used authors such as Aristotle (2005), Fiorin (2016), Perelman and Olbrechts-Tyteca (1996), emphasizing the notions of emotion and value, in addition to linguistic elements, essential for the functioning of the argumentation. In the corpus analyzed, we note the presence of strategies aimed at mobilizing and adhering to the theses advocated by the speakers, noting that these discourses are antagonistic, facing the same auditorium. In this sense, the mobilization of values, as well as the strategies cited are distinct and point to opposite directions in relation to the desired effects.
\end{abstract}

Keywords: New Rhetoric. Argumentation. Emotions. Values. 


\section{Introdução}

Os retóricos gregos e romanos criam que a fala pública e o debate era o que havia de mais civilizado no homem, por isso os colocavam como o pilar da base civilizatória humana, já que possibilitavam que se revidasse com palavras o que o animal revidaria somente com o corpo. Nas palavras de Aristóteles, "seria absurdo que a incapacidade de defesa física fosse desonrosa, e o não fosse a incapacidade de defesa verbal, uma vez que esta é mais própria do homem do que o uso da força física" (ARISTÓTELES, 2005, p. 94).

Esse modo de pensar não chegou ao século $\mathrm{XX}$, ao menos não até a primeira metade desse século, período em que puderam ser vistas duas guerras mundiais, motivadas por interesses de cunho político. Tais interesses foram compreendidos por poucos sujeitos ao longo da história, principalmente aqueles que podemos denominar de "sujeitos políticos", devido a compreendem que somente o uso da palavra possibilita interrelacionarem-se com os demais indivíduos de uma comunidade. Tais sujeitos entendiam que os detentores do poder da palavra eram os mesmos que guiavam para os diferentes lados dos confrontos as diversas nações.

A força das palavras encontrava-se dispersa para a maioria dos indivíduos, os quais sucumbiam à crença de ser a "linguagem das ciências", ao contrário da fala humana ordinária, o que nos tornava verdadeiramente humanos. Em suma, cria-se que as discussões acerca de qualquer assunto deveriam ficar a cabo dos políticos profissionais - indivíduos eleitos e remunerados para o exercício de cargos executivos e legislativos -, e que aos homens sábios restava o que agora era para eles a mais humana das artes, a ciência, como contraponto a tudo o que é comum. Não passava pela mente dessa maioria que eles também eram homens políticos, assumindo que viviam em um terreno constituído por discussões1.

A maioria dos indivíduos não sabia que aquilo que desprezava, ou seja, a fala ordinária, enquanto forma de conhecer o mundo comum dos homens e de nele agir, era o possibilitador da tomada de rumo em uma comunidade humana, habitada por diferentes indivíduos. Esqueceram estes que a arte de “viver entre homens" - parafraseando Arendt (2018) -, é a única possibilidade

\footnotetext{
1 Sobre a distinção entre "discussão" e "disputa", ver as importantes reflexões realizadas por Danblon (2004) acerca do debate em uma sociedade democrática.
} 
possível de ação e que essa arte é, por excelência, política. Ora, tudo o que é político refere-se ao terreno da linguagem e, concomitantemente, ao terreno da retórica e da argumentação2.

Mesmo sendo pertencentes a uma comunidade, os indivíduos negligenciaram a esfera da discussão humana, tais como a incerteza, como ponto para debate, a fala pública, a capacidade de convencerem e de aceitarem ser convencidos3. Tornaram-se incapazes de viver igualmente entre os demais a partir do momento no qual esqueceram que viviam em uma sociedade política, cuja significância encontrava-se na linguagem verbal, própria do humano. Nas palavras de Arendt:

\begin{abstract}
O motivo pelo qual talvez seja prudente desconfiar do julgamento político dos cientistas qua [sic] cientistas não é, em primeiro lugar, a sua falta de "caráter" que não tenham se recusado a desenvolver armas atômicas -, nem a sua ingenuidade - que não tenham compreendido que, uma vez desenvolvidas tais armas, eles seriam os últimos a ser consultados quanto ao seu emprego -, mas precisamente o fato de que se movem em um mundo no qual o discurso perdeu seu poder" (ARENDT, 2018, p. 4).
\end{abstract}

A esfera do discurso nunca deixou de existir, pois seu apagamento implicaria o fim das relações humanas, o que nunca houve. Mesmo em estado de guerra, um diálogo, ainda que mínimo, era travado. O que houve foi a negligência dos "cientistas" de que o consenso é obtido pelo debate e, além disso, de que a arte do debate é aprendida, que existem técnicas de persuasão, as quais os retóricos estudam, técnicas que nunca foram esquecidas pelos políticos profissionais, nem pelos influenciadores das opiniões das massas. Dentre esses influenciadores estavam os mesmos que guiaram os seres humanos para as duas grandes guerras do século XX.

Após o término dessas, estudiosos da antiga arte da retórica publicaram trabalhos nos quais reconheciam que o descaso com o estudo persuasivo da fala ordinária como forma de ação e de inter-relação no meio público possibilitou que os sujeitos políticos guiassem a opinião dos indivíduos. Percebendo a necessidade de retorno aos estudos retóricos e argumentativos, a fim de compreender o modo como os indivíduos são persuadidos em uma comunidade política, apresentaram, então, uma nova

\footnotetext{
${ }^{2}$ Não distinguiremos retórica de argumentação em nosso texto.

${ }^{3}$ As implicações que esse esquecimento acarreta são trabalhadas por Angenot, em sua obra de 2008.
} 
retórica como método necessário à compreensão da persuasão. Referimo-nos aqui aos trabalhos de Chaïm Perelman e de Lucie Olbrechts-Tyteca, principalmente ao Tratado da Argumentação.

É em meio a uma revisão dos antigos, porém com inovações necessárias à Era Moderna, que Perelman e Olbrechts-Tyteca afirmavam, em 1958, estarem "firmemente convictos de que as crenças mais sólidas são as que não só são admitidas sem prova, mas também, muito amiúde, nem sequer são explicitadas" (PERELMAN; OLBRECHTS-TYTECA, 1996, p. 8). Os autores também admitiam que a discussão existe dentro do terreno da linguagem, e somente nele, não sendo possível haver um ponto de vista único sobre um assunto. Esse posicionamento confronta diretamente o conceito de evidência - pilar do pensamento científico posterior a Descartes -, pois somente questionando esse conceito poderia ser erguida uma teoria da argumentação. Mesmo porque, se se concede existência à ideia de evidência, como seriam possíveis pontos de vista opostos acerca de um mesmo assunto? Como seria possível, como de fato ocorre, que para auditórios distintos sejam elaboradas argumentações distintas e que tais argumentações não sejam nem corretas, nem erradas, apenas aceitáveis (PERELMAN; OLBRECHTS-TYTECA, 1996)? Além disso, voltando o olhar para os possíveis pontos de vista destoantes, como explicar a adesão a posicionamentos diferentes construídos em um mesmo auditório?

Como temos por intenção compreender melhor o funcionamento de argumentações discordantes em relação a uma mesma temática, propomonos analisar, dentre várias alternativas possíveis, a peça Júlio César, de Shakespeare. Intentamos concentrar nosso interesse nos dois discursos construídos por Brutus e por Marco Antônio a partir da temática do assassinato de César, no Ato III, Cena II da peça. Nesses discursos, há vários pontos de vista em jogo, mas dois em particular nos interessam: um, no qual Brutus procura persuadir seus interlocutores de que César precisava ser morto para um bem maior, e outro, no qual Marco Antônio toma o caminho do extremo oposto ao ponto de vista de Brutus.

Visaremos, em nossa análise, averiguar como ocorre o contato do locutor com seus interlocutores no corpus selecionado, a fim de possibilitar que estes o ouçam e prestem nele atenção. Procuraremos verificar como os 
locutores constroem as imagens de si e de seus interlocutores na cena, como são construídas as argumentações de Brutus e de Marco Antônio durante seus discursos. Para isso, examinaremos os valores presentes nas argumentações das personagens, as emoções projetadas em seus discursos, os quais são concernentes ao acontecimento da morte de César.

Os discursos de Marco Antônio e de Brutus, tal como criados por Shakespeare, são ainda bastante presentes nos dias atuais, seja devido à sua beleza literária, sejam pelas temáticas da traição, da amizade, da responsabilidade pelos atos cometidos, da enganação, da astúcia vistas nesses discursos. A nós, porém, interessa o caráter argumentativo presente na cena, pois há nela uma mescla entre o político4, o jurídico e o epidítico: ao mesmo tempo em que se busca saber o que seria o melhor ou o pior para Roma, julgam-se as virtudes de César, se ele era ou não um tirano, além de sua figura ser exaltada por Marco Antônio em uma argumentação que intenta levantar os ânimos da população contra os algozes de César.

Não obstante, a argumentação dos personagens é exemplo de argumentação eficaz, o que pode ser inferido pelos efeitos produzidos nos interlocutores. É preciso também referenciar que Perelman e Olbrechts-Tyteca constantemente se referem à fala de Marco Antônio, na peça, como exemplo de discurso argumentativo.

\section{Para a legitimidade do assassinato de César}

César está morto, morto a punhaladas pelos senadores romanos. Além destes, encontra-se no Senado, na cena do assassinato, também Brutus, a quem César muito considerava e que lhe dá o último golpe. Agora os assassinos necessitarão explicar-se perante o povo romano, admirador de César. Os senadores creem que Brutus conseguirá amansar a ira da multidão e, para isso, combinam que ele discurse, argumentando sobre a necessidade de César ser morto.

\footnotetext{
${ }^{4}$ É necessário considerar que, apesar de a análise do discurso e a retórica pontuarem não vivermos atualmente mais em uma época que considera "tudo" como política (BONNAFOUS, 1999), nem em uma na qual se pensa que toda análise discursiva é uma análise do discurso político (MAINGUENEAU, 1995), consideramos que esse domínio discursivo ainda se faz presente de modo forte em meio a outros discursos, como o literário. Isso ocorre, principalmente, devido ao político dizer respeito à gestão da vida em comum, às decisões sobre o que seria e o que não seria melhor para a coletividade, bem como aos assuntos públicos, de modo geral.
} 
Marco Antônio, leal amigo de César, também quer discursar. Os senadores permitem, após longa discussão, que ele se dirija à multidão depois de Brutus falar. Entretanto, é-lhe avisado que nada de mau poderá dizer ao povo sobre Brutus ou sobre os senadores, ao que ele consente. Brutus, então, vai à frente do Senado para dirigir-se à multidão.

Nesse ponto, é importante ressaltarmos que Brutus precisa tomar a palavra para ser ouvido, o que constitui uma das questões mais sensíveis ao locutor. Brutus, no entanto, apresenta caracteres que lhe são oportunos. Ele era amigo de César, o que muito favorece sua imagem. Essa condição o coloca pretensamente como uma das últimas pessoas a quererem fazer-lhe mal, sem que houvesse razão para tanto. Além disso, é querido por muitos senadores, um cargo que concentrava grande admiração e respeito dos romanos ao seu ocupante, ainda que não implicasse "poder" (o qual residia no povo)5. Sua palavra era ouvida com respeito imenso em vista de tudo isso.

A multidão furiosa clama por explicações acerca do que ocorreu com César, que agora está morto: "Queremos satisfação, deem-nos uma satisfação" (SHAKESPEARE, 2006, p. 319). Quem explicará a morte do imperador, porém, será seu algoz e, por isso, será preciso lançar mão de diferentes técnicas argumentativas.

O locutor inicia sua fala apresentando-se como um equivalente dos que o escutam, aproximando-se dos seus interlocutores e os preparando para a argumentação que se seguirá em sua fala inicial: "Romanos, compatriotas e amigos" (SHAKESPEARE, 2006, p. 319).

A seleção dos termos lexicais de identificação do eu para com o outro "romanos", "compatriotas" e "amigos" - colocam Brutus e os demais cidadãos em posição equivalente (mas não igual) nos aspectos evocados pelas origens político-culturais ("romanos" e "compatriotas") e afetivas ("amigos").

A imagem que Brutos evoca, procurando trazer o povo para próximo de si e de suas ideias, está próximo do que Perelman e Olbrechts-Tyteca

\footnotetext{
${ }^{5}$ Em seu texto sobre o conceito de autoridade, Arendt realiza uma trajetória temporal, a fim de explicar o conceito. Roma é um caso singular, no qual "Aqueles que eram dotados de autoridade eram os anciãos, o Senado ou os patres, os quais a obtinham por descendência e transmissão (tradição) daqueles que haviam lançado as fundações de todas as coisas futuras, os antepassados chamados pelos romanos de maiores" (ARENDT, 1997, p. 164).
} 
elaboram sobre a noção de orador e auditório, pois constitui uma dualidade entre o eu e o outro, ou seja: não se trata mais somente da imagem de si no discurso, mas da imagem de si do locutor e da imagem que o locutor constrói de seus interlocutores como co-construções discursivas e pré-discursivas.

O termo ethos é relevante para diversas análises, mas para a que evocamos não é a mais frutífera, apesar de, em muitas ocasiões, ser necessária sua utilização, principalmente pela falta de um termo melhor que o possa substituir. No entanto, lançar mão das terminologias "imagem de si" e "imagem do outro" não somente é uma questão de nomenclatura, mas de posicionamento teórico, pois seguindo a esteira de Lima (2006), em seu estudo sobre a argumentação jurídica, percebemos que a construção da imagem de si não evoca somente a imagem discursiva do orador, mas mobiliza um conjunto de crenças, de levantamentos culturais, de valores que levam à proximidade com o outro ${ }^{6}$. Conforme a autora, "uma boa imagem de si reforça o poder da imagem criada sobre o outro, além do fato de que a imagem prévia do outro também seja de extrema importância na construção da imagem de si" (LIMA, 2006, p. 147). Inferimos dessas palavras que a construção da imagem de si é dependente da imagem que se constrói do outro e que a imagem construída do outro influi nos rumos da imagem de si no decorrer de um discurso.

Retomando o discurso de Brutus, outro elemento que o autoriza a tomar a palavra advém da imagem pré-discursiva ${ }^{7}$ que os interlocutores dele possuem, a qual é elaborada "com base no papel que o orador exerce no espaço social (suas funções institucionais, seu status e seu poder), mas também com base na representação coletiva ou no estereótipo que circula sobre sua pessoa" (AMOSSY, 2018, p. 90). Essa imagem, além de ser um dos

\footnotetext{
${ }^{6}$ Quando aqui nos referimos ao termo “outro”, não pensamos somente no interlocutor visível, encarnado em um corpo físico, mas em uma idealização próxima do que fazem Perelman e Olbrechts-Tyteca, em seu Tratado, porém, diferente desses autores, compreendemos que o "outro" não é somente uma construção de um auditório que se pretende persuadir, mas uma construção necessária para que toda interação verbal seja possível.

${ }^{7}$ A esse respeito, consideramos esclarecedoras as palavras de Amossy, quando está diz: "O ethos [sic] discursivo mantém relação estreita com a imagem prévia que o auditório pode ter do orador ou, pelo menos, com a ideia que este faz do modo como seus alocutários o percebem. A representação da pessoa do locutor anterior a sua tomada de turno - às vezes denominada ethos prévio ou pré-discursivo - está frequentemente no fundamento da imagem que ele constrói em seu discurso: com efeito, ele tenta consolidá-la, retificá-la, retrabalhá-la ou atenuá-la" (2004, p. 221).
} 
muitos elementos que o autorizam a falar diante do povo, cria expectativas acerca do que ele dirá a respeito do assassinato de César. Trata-se de uma imagem advinda do seu cargo como representante do povo, do seu histórico de amizade com César, do seu grau de nobreza e do seu hipotético amor por Roma. Tudo isso retira o locutor da situação delicada em que se encontraria qualquer outro que não tivesse esses devidos caracteres. Esses elementos autorizam Brutus a dizer: "Ouvi-me com paciência até o fim. Romanos, compatriotas e amigos! Acreditai-me por minha causa, e ficai em silêncio para poder ouvir. Acreditai-me por minha honra, e respeitai minha honra para poder acreditar" (SHAKESPEARE, 2006, p. 319).

O locutor procura abrandar a fúria dos seus interlocutores, e o faz recorrendo a uma construção sintática por meio da qual expõe a imagem prédiscursiva como fator relevante para ser ouvido, imagem advinda de um imaginário construído anteriormente ao discurso e afirmada no decorrer deste, resgatando a memória do que os interlocutores sabem a seu respeito e fixando memórias novas.

Brutus, fala em nome de todos os senadores, dele próprio e da vontade popular, afirma à multidão: "Censurai-me em vossa sabedoria e despertai vossos sentidos para julgar melhor" (SHAKESPEARE, 2006, p. 319-320), a fim de apresentar aos interlocutores o poder destes decidirem. Poder imaginário, pois estes somente precisam consentir à persuasão de Brutus.

Os romanos são pintados por Brutus como sujeitos sábios, os quais, sem preconceitos, serão capazes de ouvi-lo e de discernir se o que ele fez a César, ao governante amado, foi algo que visou ou não o bem do povo. Sua argumentação procura levar os interlocutores a imaginarem-se soberanos, quando o que verdadeiramente procura é abrandar nestes a emoção da ira, decorrente da morte de César, pois, se como mostra Aristóteles, "a ira é um desejo acompanhado de dor que nos incita a exercer vingança explícita devido a algum desprezo manifestado contra nós, ou contra pessoas da nossa conivência, sem haver razão para isso" (ARISTÓTELES, 2005, p. 161), o que Brutus almejará fazer será mostrar ao povo que havia razões para César ser morto. 
A fim de executar seu empreendimento, Brutus vale-se de lugares comuns, os quais intentam levar seus interlocutores a estabelecer para com ele a emoção da amizade:

Se houver alguém nesta assembleia, algum querido amigo de César, a ele eu direi que o amor de Brutus por César não foi menor do que o seu. Se então ele perguntar por que Brutus levantou-se contra César, esta é a minha resposta: não foi porque amei menos a César, mas porque amei mais a Roma. Preferiríeis vós que César estivesse vivo, para que morrêsseis todos escravos, a que César estivesse morto, para que viverdes livre? Porque César me amava, choro por ele; porque foi feliz, regozijo-me; porque foi bravo, honro-o; mas porque era ambicioso, matei-o (SHAKESPEARE, 2006, p. 320).

E prossegue:

Quem há aqui tão baixo que quisesse ser escravo? Se há alguém, que fale, pois a ele eu ofendi. Quem há aqui tão rude que não quisera ser romano? Se há alguém, que fale; pois a ele eu ofendi. Quem há aqui tão vil que não ame o seu país? Se há alguém, que fale; pois a ele eu ofendi. Espero uma resposta (SHAKESPEARE, 2006, p. 320).

Nesses trechos, duas questões hão de ser observadas. Primeiro, a conclamação à emoção da amizade de Brutus pelo povo de Roma. Brutus segue os padrões aristotélicos a respeito da amizade, segundo os quais nossos amigos são aqueles que se alegram com nossa alegria e se entristecem com nossa tristeza, os que nos auxiliam em nossos interesses, não por causa do benfeitor, mas unicamente por causa de nós (ARISTÓTELES, 2005, p. 170). Brutus possui a intenção de apresentar-se e ser reconhecido pelo povo romano como um amigo seu, maior do que o era César, afinal, ele salvara o povo da escravidão a que poderiam ter sido submetidos. Por meio do recurso a essa emoção, notamos a ira do povo dar lugar à celebração ao bemaventurado Brutus: "Vive, Brutus, vive! Vamos levá-lo em casa, com um desfile. Fazer-lhe a estátua junto aos ancestrais. Que ele seja César" (SHAKESPEARE, 2006, p. 300).

Outro ponto importante relaciona-se à mobilização do valor da ambição como motivo para a morte de César. O argumento de Brutus encontra-se com o raciocínio de que César era ambicioso e por isso precisava ser morto. Esse raciocínio traz à tona os imaginários acerca da ambição, a qual seria um valor demasiado negativo para um governante, sobrepondo-se a outros, de tal forma, que legitimaria mesmo um assassinato. 
Nesse ínterim, debatemo-nos com a hierarquização dos valores, apresentada por Perelman e Olbrechts-Tyteca, segundo os quais "O que caracteriza cada auditório é menos os valores que admite do que o modo como os hierarquiza" (PERELMAN; OLBRECHTS-TYTECA, 1996, p. 92), o que significa caracterizá-los por grau de superioridade, de importância, de benefício etc. Nesse caso, a ambição de César é um valor indesejado, pois, pela argumentação de Brutus, poderia levar o povo romano à escravidão. Enquanto isso, a abnegação de Brutus é vista como um valor positivo, já que advogaria ao povo a permanência da liberdade.

Brutus também argumenta aos romanos, contrapondo-lhes a aceitação do que diz ou o possível desprezo e condenação dos pares do interlocutor, ao afirmar que aceitar aquilo que ele chama de "ambição de César" é entregar-se à baixeza, à rudeza e à vilania. O algoz pinta sua imagem como a de um salvador, enquanto a do povo, como a dos salvos. O primeiro é um benfeitor, os outros são os beneficiados. Cabe a eles agradecê-lo e amá-lo pelo que fez, pois, em sua argumentação, Brutus caracteriza-se como aquele que não se importa tanto com si próprio, mas com os outros, o povo romano.

As perguntas de Brutus visam não somente a levar o interlocutor à reflexão acerca do que significa "querer ser escravo", "não querer ser romano", "não amar seu país", mas também provocar o silêncio dos interlocutores, que não possuem coragem de manifestar concordância em relação às perguntas, uma vez que concordar com as afirmações ali contidas poderia levar o interlocutor a ser rechaçado por seus pares. Além disso, como cada interlocutor procurará preservar-se não respondendo a Brutus (pois nesse caso responder é incriminar-se), tornam-se obrigados a refletirem acerca do significado dos vícios elencados por Brutus (vilania, rudeza, baixeza) quando direcionados ao contexto político, o que serve como preparação para melhor recepcionar, tanto o que Brutus já disse, quanto o que ainda dirá sobre os motivos que o levaram, junto com os senadores, ao assassinato de César.

Brutus também se guia pela imagem de homem respeitoso (virtuoso), que considera, sem quaisquer preconceitos, as opiniões alheias, o que é manifestado pela repetição do enunciado "Se há alguém, que fale; pois a ele eu ofendi”. Ao que ele recebe como resposta: “Ninguém, Brutus, ninguém”. E 
retalia "Então não ofendi ninguém. Não fiz mais a César do que faríeis vós a Brutus" (SHAKESPEARE, 2006, p. 320).

Brutus coloca os romanos lado a lado com ele próprio, fazendo com que se insiram em seu lugar, com que as imagens que cria de si e as que cria do outro se equiparem, de modo que os plebeus se vejam/imaginem, por um momento, como iguais ao nobre.

Brutus, ao enunciar "Não fiz mais a César do que faríeis vós a Brutus", coloca-se como aquele que fez a coisa certa, aquele que agiu como qualquer outro "patriota honrado" teria agido ou deveria tê-lo feito.

"Com isso eu parto, eu que assassinei aquele a quem amava pelo bem de Roma, e tenho a mesma adaga para mim, quando aprouver ao meu país ter a necessidade da minha morte" (SHAKESPEARE, 2006, p. 320). Por meio dessas palavras, Brutus apresenta-se como um patriota, disposto a dar sua vida pela pátria, bem como capaz de cometer assassinato por ela. Contudo, nesse ponto a questão central da Cena 2, Ato 3, de Júlio César aparece. A questão não é se César era culpado ou inocente, se Brutus e os senadores são ou não culpados, pois essas são questões secundárias que contornam o argumento principal, o qual se encontra implícito em meio ao debate. O ponto principal de toda essa argumentação é sobre a legitimidade de um assassinato em nome da pátria. Não à toa, tanto o discurso de Brutus, quanto o de Marco Antônio são povoados de termos e expressões referentes aos temas ligados ao patriotismo como: "nobre”, “compatriotas", “honra”, “sabedoria”, "assembléia”, “livres”, "bravura”, "país”, "patrícios”. O debate é sobre haver pessoa que mereça ou deva ser morta para que haja a liberdade ou o bemestar das demais.

Cremos que isso pode ser atestado por passagens como a que se segue ao discurso de Brutus, quando, por fim, a multidão afirma: "César foi um tirano" e "Isso é certo. É uma benção ver Roma livre dele" (SHAKESPEARE, 2006, p. 321). Lembrando que esses dizeres vinham dos que há pouco o amavam.

\section{Em defesa de César e contra Brutus}

A adesão dos espíritos, possivelmente, é a consequência precípua na relação existente entre orador e auditório ao levarmos em consideração os 
pressupostos teóricos desenvolvidos por Perelman e Olbrechts-Tyteca, os quais consideram, para essa adesão, tanto a língua de que se servem os sujeitos, quanto os valores por eles compartilhados, além do prestígio do orador.

Para os autores, a argumentação se constrói mediante a seleção e organização dos dados, e, nesse sentido, é mister apontar o procedimento de apresentação de certos aspectos que implicam naquilo que o Tratado destaca como a escolha das qualificações voltadas para enfatizar e completar o conhecimento prévio a respeito de determinado objeto.

O curioso no discurso de Marco Antônio, quando levamos em consideração as qualificações, é que não há presença de qualificadores voltados para complementar determinadas informações, mas, ao contrário, faz-se presente o uso irônico 8 das qualificações que visariam, por um lado, desmentir o sentido semântico canônico (Brutus era, de fato, um homem honrado?) e, por outro, transmitir tal sentido para a figura de César, vítima da traição de Brutus.

Trazendo nosso corpus para a discussão, a conduta de Brutus é enunciada de forma a deixar rastros implícitos de uma desconstrução semântica, como ocorre, por exemplo, com a ideia de honradez. Isso foi desenvolvido tacitamente, pois existem prerrogativas que, à luz de Perelman e Olbrechts-Tyteca, visariam determinar a ordem na argumentação, a saber, o estabelecimento de premissas, a explicitação e a estabilização de acordos. Em nosso entender, o discurso de Marco Antônio, ao menos em seu início, respeita as diretrizes argumentativas - havia um acordo, imposto por Brutus, que obrigaria Marco Antônio a não enunciar nenhuma ideia contrária ao modus operandi adotado pelos executores de César: "Não fale contra nós no funeral" (SHAKESPEARE, 2006, p. 296). Entretanto, esse respeito não se sustenta, pois o que vemos é uma subversão às regras impostas, contrárias à intencionalidade do orador.

\footnotetext{
${ }^{8}$ Tomamos o significado de ironia conforme o aponta Fiorin, ou seja, como uma forma de utilização da linguagem em que se intensifica um significado por meio da inversão de um sentido. Conforme o autor: "A ironia apresenta uma atitude do enunciador, pois é utilizada para criar sentidos que vão do gracejo até o sarcasmo, passando pelo escárnio, pela zombaria, pelo desprezo, etc. Na verdade, são duas vozes em conflito, uma expressando o inverso do que disse a outra; uma voz invalida o que a outra profere. Assim, a ironia é um tropo em que se estabelece uma compatibilidade predicativa por inversão, alargando a extensão sêmica dos pontos de vista coexistentes e aumentando sua intensidade" (FIORIN, 2016, p. 70).
} 
Marco Antônio não possui por caução "a adesão expressa dos interlocutores a suas teses iniciais" (PERELMAN; OLBRECHTS-TYTECA, 1996, p. 118), ou seja, ele precisaria alcançar tal efeito por meio da eficácia argumentativa de seu proferimento. O orador tem consciência do ambiente hostil que receberá seu discurso, justamente pelo fato de que Brutus teve êxito em inflar os ânimos do auditório a favor do assassinato de César. Para reverter a construção imagética da figura do imperador, Marco Antônio lança mão de algumas estratégias discursivas. Duas acabam se interligando, sendo merecedoras de destaque: o discurso relatado e a repetição.

O primeiro emerge por meio do uso indiscriminado da ambiguidade. Maingueneau (1997) destaca as contribuições de Alain Berrendonner e Catherine Kerbrat-Orecchioni para o estudo do discurso relatado a partir da citação. O primeiro acredita que as asserções oriundas de um terceiro visariam a não garantia da "verdade" daquilo que foi enunciado, já Kerbrat-Orecchioni, por seu turno, acredita na citação como estratégia de não responsabilização do orador por aquilo que está sendo proferido. Maingueneau sintetiza essas ideias através da noção de distanciamento, em um jogo de aproximação e afastamento do dito, segundo o qual "Pode-se tanto dizer que 'o que enuncio é verdade porque não sou eu que o digo', quanto o contrário” (1997, p. 86).

Ao enunciar "O honrado Brutus disse que César era ambicioso" (SHAKESPEARE, 2006, p. 322), o que se percebe é um descolamento do orador em relação ao conteúdo semântico do discurso proferido. Isso é ainda mais evidenciado na construção "[César] foi meu amigo justo e dedicado, mas Brutus disse que ele era ambicioso" (SHAKESPEARE, 2006, p. 322).

No bojo do discurso relatado, aparece a estratégia da repetição, a qual adjetiva a figura do traidor: "Brutus disse que ele era ambicioso" e "Brutus é um homem honrado". Cada construção linguística possui importância na elaboração do ponto de vista que se almeja construir em uma argumentação. Seja uma interjeição, o uso do adjetivo posto antes ou depois do nome ao qual se refere, o uso ou não de um artigo, bem como a repetição de um termo ou expressão.

Fiorin aponta que a figura da palilogia (repetição de versos e orações) carrega consigo a orientação de aumentar a extensão textual "para tornar mais intenso o sentido" (2016, p. 127). Em nossa análise, o postulado de Fiorin 
mostra-se adequado, pois o sentido almejado pelo orador é justamente o de desconstruir semanticamente aquilo que é proferido, e a repetição visaria à intensificação desse sentido. Isso pode ser notado ao longo do desenvolvimento do discurso e, diante disso, os termos "honrado" e "ambicioso" acabam tendo seu horizonte semântico canônico ratificado pelo orador através da estratégia da ironia.

A fala de Marco Antônio apresenta uma notória bidimensionalidade, uma marca proeminente de textos estruturados por meio da ironia. Dessa forma, é pertinente observar que as estratégias argumentativas operadas pelo orador em questão "cifram" a linguagem, com a finalidade de orientar seu discurso para, em primeiro lugar, respeitar as diretrizes iniciais estipuladas pelos senadores e, em seguida, inflamar tacitamente o auditório.

Isto posto, ao classificar o proferimento de Marco Antônio como pertencente ao gênero epidítico, é fundamental entender quais valores estão sendo colocados em questão. Perelman e Olbrechts-Tyteca oferecem uma contribuição significativa para compreender o papel argumentativo do gênero epidítico, que estaria muito além de um mero juízo de valor ou de uma louvação. A palavra-chave para compreendermos a problematização oferecida pelos autores é valor. Vejamos o que eles têm a nos dizer:

A argumentação do discurso epidíctico se propõe aumentar a intensidade da adesão a certos valores, sobre os quais não pairam dúvidas quando considerados isoladamente, mas, não obstante, poderiam não prevalecer contra outros valores que viessem a entrar em conflito com eles. $O$ orador procura criar uma comunhão em torno de certos valores reconhecidos pelo auditório, valendo-se do conjunto de meios de que a retórica dispõe para amplificar e valorizar (PERELMAN; OLBRECHTS-TYTECA, 1996, p. 56-57).

Algumas questões concernentes ao excerto anterior merecem atenção. Primeiramente, é válido destacar a ideia de conflito, que se mostra inerente às condições de produção dos dois discursos: o de Brutus e o de Marco Antônio. Fazendo a restrição para a fala de Marco Antônio, o que se nota é a existência de um determinado valor - honra - e sua negação, amparada pela adversativa “mas" e complementada pela ideia de ambição: 


\begin{abstract}
Ele trouxe pra Roma mil cativos
Cujo resgate enchia os nossos cofres;

Mostrou-se assim a ambição de César?

Quando o pobre clamava ele sofria:

Ambição deve ter mais duro aspecto;

Mas Brutus diz que ele era ambicioso,

E Brutus é um homem muito honrado

Vós todos vistes que, no Lupercal,

Três vezes lhe ofertei a real coroa:

Três vezes recusou. Isso é ambição?

(SHAKESPEARE, 2006, p. 322)
\end{abstract}

A partir do fragmento, destaca-se o trabalho com alguns valores fundamentais, objetivando à construção e desconstrução das imagens de si e do outro. É válido enfatizar que o excerto compreende o introito do discurso, momento-chave em que o orador precisa "preparar o terreno" para a modificação do clima construído pelo discurso de Brutus. Com isso, mostramse proeminentes os valores positivos de amizade, generosidade, compaixão, desapego e honra, contrastados com a ideia de ambição.

Em determinado ponto do proferimento, o orador afirma não querer contestar Brutus, mas, ao contrário, informar ao auditório o que ele "realmente" sabe. Ora, se o que ele conhece destoa significativamente do discurso de Brutus, é evidente que haverá uma contestação. Tanto que, já nos primeiros comentários dos plebeus, notamos uma modificação do clima que, vale dizer, pautará o restante do proferimento. Se o primeiro plebeu diz: "Acho que tem razão no que ele diz", o segundo retorquirá: "Pensando bem em toda essa questão, / César foi muito injustiçado", ao que se juntarão o terceiro: "Muito! / Eu só temo que venha outro pior" e o quarto plebeus: “Ouviram? Ele não quis a coroa; / É óbvio que não era ambicioso”, seguidos novamente pelo primeiro: "E se não era, alguém vai pagar caro" (SHAKESPEARE, 2006, p. 322-323).

A última fala destacada no parágrafo anterior pode ser considerada 0 ponto fulcral para a construção discursiva do proferimento de Marco Antônio. Em primeiro lugar, ela abre a possibilidade para o contraditório, isto é, há uma cisão na adesão plena supostamente obtida pela fala de Brutus. Em segundo lugar, o efeito desse contraditório, e aqui podemos destacar a força argumentativa do exemplo, será decisivo para o sucesso da construção da 
imagem do outro - César e Brutus (ainda que a imagem deste último seja negativa).

Segundo Aristóteles, a argumentação pelo exemplo é uma estratégia comum a todos os gêneros e ela pode ser acionada de duas formas: "uma consiste em falar de fatos anteriores, a outra em inventá-los o próprio orador" (2005, p. 206). De acordo com o filósofo, inventar fatos se daria mediante a utilização de parábolas e fábulas, algo que se mostra alheio ao procedimento adotado por Marco Antônio. Portanto, falar de fatos anteriores é o que encontra ressonância no discurso em questão, conforme os excertos destacados em linhas anteriores: o que César fez ("Ele trouxe pra Roma mil cativos / Cujo resgate enchia os nossos cofres"), o que César deixou de fazer ("Três vezes lhe ofertei a real coroa: / Três vezes recusou").

Refinando ainda mais a ideia de exemplificação, podemos evocar novamente Perelman e Olbrechts-Tyteca, que dissertam sobre o que comumente pode se fazer manifesto na argumentação: a presença. É sabido que exemplo e presença não são sinônimos, eles podem funcionar em uma relação de complementaridade, no sentido de obter a adesão junto ao auditório.

Certos mestres da retórica, partidários de efeitos fáceis, preconizam, para emocionar o público, o recurso a objetos concretos, como a túnica ensanguentada de César que Antônio brande aos romanos, como os filhos do réu que são levados perante os juízes para despertar-Ihes a piedade. $O$ objeto real deve acarretar uma adesão que sua mera descrição parece incapaz de provocar; é um auxiliar precioso, contanto que a argumentação lhe valorize os aspectos úteis (PERELMAN; OLBRECHTS-TYTECA, 1996, p. 133).

Os autores parecem possuir uma posição dúbia em relação à utilização do objeto concreto, que seria um recurso negativo, justamente pelo fato de sinalizar a possibilidade de distrair o auditório. Contudo, eles apontam que tal estratégia pode ser um "auxiliar precioso", se amparado por uma argumentação adequada.

Parece-nos que a fronteira entre o uso pertinente, pensando em Perelman e Olbrechts-Tyteca, e o uso exagerado da presença é porosa e não nos cabe aprofundar a respeito disso nesse curto espaço. O que nos parece interessante é destacar o papel do recurso ao objeto concreto no discurso de Marco Antônio, pensando na efetividade da adesão do auditório. Tal 
estratégia é perceptível na fala do orador em dois momentos: quando Marco Antônio apresenta o testamento, que traria benesses a todos os cidadãos romanos, e quando mostra o manto ensanguentado do imperador, seguido da apresentação das cicatrizes do cadáver.

Eis um escrito com o selo de César; Achei-o no seu quarto; é a sua palavra.

Se o povo ouvisse aqui seu testamento, O qual, perdão, eu não pretendo ler, Ele iria beijar suas feridas,

Molhar seus lenços no sangue sagrado, Tentar guardar um cabelo de César $\mathrm{E}$, ao morrer, haveria de testar, Deixando-o qual legado precioso, Aos seus herdeiros

(SHAKESPEARE, 2006, p. 302-303).

O que Marco Antônio mobiliza no fragmento acima? Percebemos a existência da estratégia do falso suspense, como forma de instigar o auditório, pois mesmo enunciando que não iria mostrar o testamento, somos sabedores de que o recurso a esse objeto concreto é uma das peças-chave para a construção argumentativa, principalmente se pensarmos no valor que o testamento mobiliza: a figura do benfeitor. Ao perceber o sucesso das intervenções anteriores, Marco Antônio se mostra mais incisivo na mobilização dos espíritos ao exaltar a figura de César, algo que inicialmente afirmou não ser seu objetivo: "Venho enterrar a César, não louvá-lo" (SHAKESPEARE, 2016, p. 301). Com isso, o cenário foi preparado para a apresentação do objeto concreto, prova de traição e do assassinato daquele que era querido pelo povo.

Se tendes lágrimas, chorai agora.

Conheceis este manto. Eu inda lembro

A vez primeira em que ele o usou [...]

Vede aqui onde Cássius o feriu,

E onde o rasgou a inveja de Casca.

Aqui o apunhalou o amado Brutus,

E quando este puxou para fora a faca,

Vede o sangue de César a segui-la,

Assim como se corresse porta afora

Pra ver se o golpe fora do cruel Brutus.

Pois esse Brutus, como vós sabeis,

Era o anjo de César. Vós, oh deuses,

Julgai o quanto César o amava!

Essa foi a ferida mais cruel,

Pois quando César o viu golpeando-o,

$A$ ingratidão, mais forte que os traidores,

Venceu e arrebentou seu coração

(SHAKESPEARE, 2006, p. 304-305). 
Esse fragmento é rico no procedimento de guinada argumentativa, pois havia um acordo, um estabelecimento de premissas, que, teoricamente, deveria ser cumprido pelo orador. Para esse acordo, Brutus e os demais senadores são denominados de pessoas honradas. Aqui, ao contrário, Brutus é cruel. Há a mobilização de valores e de emoções significativas para a tentativa de influenciar o auditório. O que mais salta aos olhos é a negação da amizade: o manto é apresentado como um elemento personificador da bravura de César - ele venceu os Nérvios -, ao passo que o sangue simboliza a negação do amor, isto é, a traição de Brutus. Não à toa, a multidão grita:

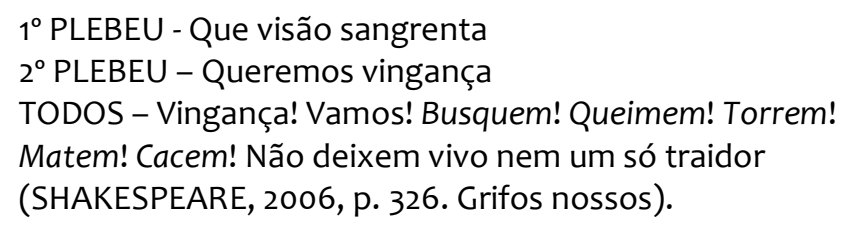

A argumentação de Marco Antônio conseguira sobrepor-se a de Brutus, ofuscando aquele que era visto como um filho por César. Os termos destacados acima nos mostram esse aspecto: o de um auditório que, após ter sido amansado por Brutus, fora encolerizado por Marco Antônio em grau maior do que se encontrava antes de Brutus tomar a palavra. Os verbos destacados simbolizam o êxito de Marco Antônio, pois são verbos de convocação, que prefiguram uma ação previamente desejada pelo defensor de César: não deixar vivo um só traidor.

\section{Considerações finais}

O desenlace da trama apresenta uma eficiência da violência simbólica, a qual é discursivizada pela negação da amizade, em relação à violência física. A despeito das inúmeras punhaladas recebidas, somente ao ver que um de seus algozes era o mais querido, César se dá por vencido. Ele não fora derrotado pelas facadas, mas pela ingratidão e traição, antitéticas à amizade.

A partir desse acontecimento, temos duas argumentações diametralmente opostas. Por um lado, Brutus e os senadores procuraram explicar para o povo a motivação da traição e, para isso, Brutus contrapôs o valor da ambição como tendo se sobressaído em César, em detrimento de 
outros valores, mais importantes ao bem-estar do povo, ao bom andamento da coisa pública.

Marco Antônio, tomando caminho inverso, procurou elementos que suscitassem na multidão a indignação. Para tanto, construiu uma argumentação cujo apelo às emoções se mostra capaz de suscitar uma resposta rápida, pois Antônio, não sendo bem-sucedido de imediato, poderia sofrer sanções dos senadores, inclusive a da morte. Ao fim, pôde-se verificar, em sua construção argumentativa, a desconstrução da imagem de César como ambicioso, a qual fora realizada por Brutus, e a construção da imagem dos algozes de César como traidores, dignos de punição maior do que a de um assassino comum.

Nas duas argumentações, o gênio criativo de Shakespeare nos apresenta a possibilidade de verificar como as imagens do locutor e do interlocutor são construídas em uma argumentação, o que poderíamos tratar por meio de distintos pontos de vista, os quais aqui apresentamos, seja o de Perelman e de Olbrechts-Tyteca (1996), seja o de Lima (2006). Cada uma das abordagens carrega consigo uma ancoragem que as distingue pela visão enfatizada.

Uma parte da tradição retórica ainda enfatiza a necessidade de se pensar a imagem do orador enquanto uma construção discursiva (do modo que pontua Aristóteles), outra a pensa como ancorada naquilo que um ser humano é (concepção de Cícero), ou imagina-se que seja. Essa dualidade, revista pela retórica a partir do século $X X$ e pela análise do discurso argumentativo, mostra-nos que seria possível não apenas pensar o orador e o auditório, assim como o eu e o outro, a partir de uma concepção ativa, da fonte do discurso, e passiva, da recepção. As imagens que cada um constrói do outro são elaboradas em uma inter-relação de confronto, e se influenciam mutuamente em uma argumentação.

Como bem vimos no corpus analisado, o discurso de Marco Antônio é construído a partir das imagens que Brutus projeta de César e do povo; que o povo projeta de Brutus, de César e do próprio Marco Antônio; que este projeta de César, de Brutus e do povo. Há imagens prévias dos interlocutores, mas essas são moldadas ao longo das argumentações e as direcionam por caminhos diversos. 
Ao término do percurso, o que se pôde perceber é que para todo acontecimento mais de um ponto de vista será possível, sendo o ponto de vista melhor aderido aquele que condiz com as diferentes expectativas dos interlocutores ao longo da argumentação, e mesmo antes desta, com um melhor conhecimento da realidade que cerca o ato de dizer, das emoções implicadas neste ato (construídas e reconstruídas ao longo da argumentação), dos valores aos quais os interlocutores aderem. Assim o é em relação à argumentação de Brutus, à de Marco Antônio e mesmo à de Shakespeare, o qual, ainda que esqueçamos, constantemente argumenta com o leitor por meio de suas personagens.

\section{Referências}

AMOSSY, Ruth. Ethos. In: CHARAUDEAU, P.; MAINGUENEAU, D. Dicionário de análise do discurso. Coordenação da tradução: Fabiana Komesu. São Paulo: Contexto, 2004. p. 220-221.

. A argumentação no discurso. Coordenação da tradução: Eduardo Lopes Piris e Moisés Olímpio-Ferreira. São Paulo: Contexto, 2018.

ANGENOT, Marc. Dialogues de sourds: traité de rhetórique antilogique. Paris: Mille et Une Nuits, 2008.

ARENDT, Hannah. Que é autoridade. In: ARENDT, H. Entre o passado e o futuro. Tradução: Mauro W. Barbosa. São Paulo: Editora Perspectiva, 1997. p. 127-187.

. A condição humana. Tradução: Roberto Raposo. Rio de Janeiro: Forense Universitária, 2018.

ARISTÓTELES. Retórica. Tradução: M. A. Júnior; P. F. Alberto; A. N. Pena. Lisboa: Imprensa-Nacional Casa da Moeda, 2005.

BONNAFOUS, Simone. L'analyse du discours politique. In: MARI, H. et al. Fundamentos e dimensões da análise do discurso. Belo Horizonte: Carol BorgesNúcleo de Análise do Discurso. FALE-UFMG, 1999. p. 317-326.

DANBLON, Emmanuelle. Argumenter en démocratie. Bruxelles: Éditions Labor, 2004. FIORIN, José Luiz. Figuras de Retórica. São Paulo: Contexto, 2016. 
LIMA, Helcira Maria Rodrigues de. Na tessitura do Processo Penal: a argumentação no Tribunal do Júri. 2006. 260 f. Tese (Doutorado em Estudos Linguísticos) Faculdade de Letras, Universidade Federal de Minas Gerais, Belo Horizonte. 2006.

MAINGUENEAU, Dominique. Présentation. Langages, Paris, n. 117, p. 5-11, 1995.

. Novas tendências em análise do discurso. Tradução: Freda Indursky. Campinas: Pontes, 1997.

PERELMAN, Chaïm; OLBRECHTS-TYTECA, Lucie. Tratado da argumentação: a nova retórica. Tradução: Maria Ermantina Galvão. São Paulo: Martins Fontes, 1996.

SHAKESPEARE. Júlio César. In: Tragédias e comédias sombrias: obras completas. Tradução: Bárbara Heliodora. Rio de Janeiro: Nova Aguilar, 2006. p. 298-308.

\section{Forma de citação sugerida}

ARCANJO, Fábio Ávila; PEIXOTO, Thiago Fernandes. Construções retóricoargumentativas em Júlio César, de Shakespeare. EID\&A - Revista Eletrônica de Estudos Integrados em Discurso e Argumentação, Ilhéus, n. 19, v. 2, p. 33-53, dez.2019. DOI 10.17648/eidea-19-v2-2403. 